\title{
PENINGKATAN KEMAMPUAN REPRESENTASI MATEMATIS DAN SELF CONFIDENCE SISWA MELALUI PEMBELAJARAN HUMANISTIK BERBASIS PENDIDIKAN MATEMATIKA REALISTIK
}

\author{
Lia Rista ${ }^{1}$, Cut Yuniza Eviyanti' ${ }^{2}$, Siti Hadijah ${ }^{3}$ \\ 1,2,3 Pendidikan Matematika, STKIP Bumi Persada, Lhokseumawe, Indonesia \\ leeyarista@gmail.com
}

\begin{abstract}
Abstrak
The objectives of this study are: (1) to find out the difference of improvement of students' mathematical representation ability and students' self-confidence through humanistic learning based on realistic mathematical approaches and conventional learning reviewed (a) as a whole and (b) at the student level (high, medium, low), (2) to find out is there interaction between learning process and students' initial ability on the improvement of students' mathematical representation ability and students' self-confidence. The population of this study is all of the student in SMA Negeri 1 Lhokseumawe. The sample of this study was taken randomly consist of two classes . The two way ANAVA was used to analyzed the data of this study. The results of this study indicate that the increasement of students' mathematical representation who learned with humanistic learning based on PMR is higher than the students' who learned with conventional learning. The Increasement of students' self-confidence who learned with humanistic learning based on PMR is higher than the students who learned with conventional learning. There is interaction between learning model (problem-based learning and conventional learning) and students' initial mathematical ability toward the increasement of students' mathematical representation ability. There is interaction between learning model (problem based learning and conventional learning) and students' initial mathematical ability toward the increasement of students' self-confidence.
\end{abstract}

Keywords: Humanistic Learning Based on PMR, Mathematical Representation, and Self-Confidence.

\section{Abstrak}

Penelitian ini bertujuan: (1) Untuk mengetahui perbedaan peningkatan kemampuan representasi matematis dan self confidence siswa melalui pembelajaran humanistik berbasis pendidikan matematika realistik (PMR) dan pembelajaran biasa (PB) ditinjau dari:(a) secara keseluruhan, (b) berdasarkan level siswa (tinggi, sedang, rendah), (2) Untuk mengetahui Apakah terdapat interaksi antara strategi pembelajaran dengan level siswa terhadap kemampuan representasi matematis dan self confidence siswa. Populasi penelitian adalah seluruh siswa SMA Negeri 1 Lhokseumawe. Sampel penelitian diambil secara acak sebanyak 2 kelas. Analisis data dilakukan dengan ANAVA Dua Jalur. Hasil penelitian ini menunjukkan bahwa Peningkatan kemampuan representasi matematis siswa yang diberi pembelajaran humanistik berbasis PMR lebih tinggi daripada siswa yang diberi PB. Peningkatan self confidence siswa yang diberi pembelajaran humanistik berbasis PMR lebih tinggi daripada siswa yang diberi PB. Terdapat interaksi antara model pembelajaran dan KAM terhadap peningkatan kemampuan representasi matematis siswa. Terdapat interaksi antara model pembelajaran dan KAM terhadap peningkatan self confidence siswa.

Kata Kunci: Pembelajaran Humanistik berbasis PMR, Representasi Matematis, dan Self Confidence.

Pemerintahan saat ini terus berusaha melakukan perkembangan pendidikan yang lebih baik, untuk mengejar ketertinggalan dengan negara-negara yang terus berkembang dengan pesat seiring berubahnya era globalisasi saat ini yang lebih mendahulukan pendidikan berbasis teknologi. Karena pendidikan memiliki peranan penting dalam kemajuan suatu negara. Negara yang maju terdapat masyarakat yang akan melahirkan kemajuan dalam berbagai aspek yaitu kemajuan dalam ilmu pengetahuan dan teknologi serta peradaban yang terus semakin canggih.

George (Siswono,dkk: 2018) Pendidikan dapat dipandang dalam arti luas dan arti teknis. Pendidikan dalam arti luas mengacu pada suatu tindakan atau pengalaman yang mempunyai pengaruh 
yang berhubungan dengan pertumbuhan atau perkembangan jiwa (mind), watak (character), dan kemampuan fisik (physical ability). Pendidikan dalam arti teknis artinya pendidikan adalah proses dimana masyarakat melalui lembaga-lembaga pendidikan (sekolah, perguruan tinggi, atau lembagalembaga lain) dengan sengaja mentransformasikan warisan budaya, yaitu pengetahuan, nilai, keterampilan, dan generasi ke generasi. Dengan demikian pendidikan sangat mempengaruhi terhadap perkembangan pola pikir manusia yang berkenaaan dengan aktivitas dan proses berpikir yaitu proses berpikir analitis, kreatif, representasi, kritis, serta berpikir logis.

Mengembangkan pola pikir siswa khususnya dalam dunia pendidikan matematika berkaitan erat berkaitan erat dengan aktivitas dan proses belajar serta berpikir karena karakteristik matematika merupakan suatu ilmu dan human activity. Salah satu pengembangan kemampuan berpikir siswa adalah kemampuan representasi matematis, karena kemampuan ini menjadi salah satu kemampuan yang sangat dibutuhkan dalam pendidikan matematika saat ini.

Berdasarkan realita yang terjadi dilapangan saat melakukan observasi awal, menyatakan bahwa sekolah SMAN 1 Lhokseumawe adalah sekolah favorit yang diminati para siswa khususnya di kota Lhokseumawe, dikarenakan masyarakat menganggap bahwa sekolah tersebut mampu membuat anakanak memperoleh pendidikan yang maksimal yang mampu membawa ke jenjang yang lebih baik untuk melanjutkan pendidikan yang lebih tinggi yaitu universitas. Sekolah tersebut juga termasuk sekolah percontohan bagi sekolah lainnya, dan melakukan perubahan baik dari segi pendidikan dan proses pembelajaran serta guru-guru yang kompeten dalam bidangnya. Realita di lapangan, guru sudah mulai melakukan perubahan dari segi model pembelajaran agar siswa memiliki minat yang lebih tinggi. Akan tetapi pembelajaran yang dilakukan tidak selalu bervariasi dan masih terlihat monoton, hanya berfokus pada pemahaman konsep. Sebenarnya pemahaman konsep sangat penting di awal pembelajaran, karena konsep merupakan induk dari setiap materi. Akan tetapi setidaknya guru juga harus mampu mengembangkan pola pikir siswa melalui kreativitas, kritis, penalaran, dan representasi matematis. Karena siswa dihadapkan pada permasalahan materi nantinya.

Mengingat pentingnya kemampuan matematis yaitu salah satunya representasi dan self confidence siswa dalam dunia pendidikan yang saat ini sedang berjalan di sekolah, maka dibutuhkan suatu strategi pembelajaran yang mampu membantu pembelajaran yang mengembangkan kemampuan pemahaman, khususnya representasi matematis dan self confidence siswa. Antara lain Pembelajaran matematika humanistik yang menempatkan siswa sebagai subjek untuk membangun pengetahuannya dengan memahami kondisi-kondisi, baik dalam diri sendiri maupun lingkungan sekitarnya.

Susilo (2008) mengatakan bahwa pelajaran matematika secara humanistik berarti menempatkan matematika sebagai bagian dari kehidupan nyata manusia. Proses pembelajarannya juga menempatkan pelajar bukan sebagai obyek, melainkan subyek yang bebas menemukan pemahaman berdasarkan pengalamannya sehari-hari. Dalam kaitan ini ada beberapa pendekatan pembelajaran yang diyakini sejalan dengan pembelajaran yang menekankan sifat humanistik antara lain Pendidikan 
Matematika Realistik (PMR) yaitu pembelajaran matematika sekolah yang dilaksanakan dengan menempatkan realitas dan pengalaman siswa sebagai titik awal pembelajaran.

Berdasarkan uraian di atas, peneliti meyakini bahwa pembelajaran matematika Humanistik berbasis Pendidikan Matematika Realistik (PMR) sangat tepat digunakan untuk peningkatan kemampuan representasi matematis dan self confidence siswa. Sehingga peneliti bertujuan ingin mengembangkan kembali atau meneliti tentang: (1). Apakah terdapat perbedaan yang signifikan peningkatan kemampuan representasi matematis dan self confidence siswa yang memperoleh pembelajaran humanistik berbasis PMR dengan siswa yang memperoleh pembelajaran konvensional ditinjau dari:(a) secara keseluruhan, (b) berdasarkan level siswa (tinggi, sedang, rendah)?, (2). Apakah terdapat interaksi antara strategi pembelajaran dengan level siswa terhadap kemampuan representasi matematis dan self confidence siswa?

\section{METODE}

\section{Pendekatan dan Jenis Penelitian}

Penelitian ini berkenaan tentang peningkatan representasi matematis dan self confidence siswa melalui pembelajaran matematika humanistik berbasis PMR (Pendidikan Matematika Realistik). Metode penelitian yang dilakukan dalam penelitian ini adalah penelitian eksperimen murni (true experimental) dengan rancangan random atau disebut juga randomized pretest - postest control group design. Gambaran tentang desain ini dapat dilihat pada gambar dibawah ini. Desain penelitian ini berbentuk:

Kelas eksperimen

Kelas kontrol

\begin{tabular}{lll}
$\mathrm{O}$ & $\mathrm{X}$ & $\mathrm{O}$ \\
\hline $\mathrm{O}$ & $\mathrm{C}$ & $\mathrm{O}$
\end{tabular}

Keterangan :

$\mathrm{O}$ : Pretest dan postest

$\mathrm{X}$ : Perlakuan pembelajaran humanistik berbasis PMR.

C : Pembelajaran matematika tanpa perlakuan humanistik berbasis PMR.

Selanjutnya, untuk mengetahui secara lebih mendalam pengaruh pembelajaran humanistik berbasis PMR terhadap kemampuan representasi matematis dan self confidence siswa pada kelas eksperimen serta perbedaannya dengan kelas kontrol yang diterapkan pembelajaran konvensional.

\section{Populasi dan Sampel}

Populasi dalam penelitian ini adalah siswa kelas X SMA N 1 Kota Lhokseumawe. Pengambilan sekolah ini dikarenakan sekolah tersebut sering mengunnakan berbagai model atau metode yang menunjang kemampuan berpikir siswa dan sekolah ini juga dijadikan sebagai sekolah percontohan apabila terdapat kurikulum baru. Penelitian ini telah dilaksanakan tanggal 23 Juli 2019 samapai dengan 1 September 2019. Sedangkan sampel pada penelitian ini mengambil dua kelas dari kelas X SMA N 1 Kota Lhokseumawe. Dari kelas tersebut diambil dua kelas secara acak yaitu kelas X-MIA ${ }_{1}$ sebagai kelas 
eksperimen yang diterapkan pembelajaran humanistik berbasis PMR. Sedangkan kelas X-MIA4 sebagai kelas kontrol (pembelajaran konvensional).

\section{Tahap Pengolahan data}

Data yang diperoleh melalui pretest dan postes dianalisis menggunakan analisis statistik dan melakukan penarikan kesimpulan terhadap hasil analisis data dan kemudian penulisan laporan.

Dalam penelitian ini terdiri dua macam instrument, yaitu instrument representasi matematis dan self confidence siswa.

\section{Instrumen Representasi Matematis dan Self Confidence Siswa}

Instrumen tes yang digunakan untuk mengukur representasi matematis siswa ialah soal-soal yang berbentuk uraian. Soal uraian tersebut memuat indicator: a) Representasi visual: menyajikan kembali data atau informasi dari suatu representasi, menggunakan representasi visual untuk menyelesaikan masalah, membuat gambar pola-pola dan membuat gambar untuk memperjelas. b) Persamaan atau ekspresi matematis: membuat persamaan atau model matematika dari representasi lain, membuat konjektur, penyelesaian masalah c) kata-kata atau teks tertulis: membuat situasi masalah berdasarkan data, menuliskan interprestasi, menuliskan langkah-langkah penyelesaian serta menyusun cerita.

Selanjutnya instrumen angket Self Confidence tersebut terlebih dahulu peneliti kembangkan berdasarkan indikator yang akan diukur. Hal ini bertujuan untuk menentukan kesesuaian antara instrumen angket Self Confidence dengan indikator yang akan diukur. Angket Self Confidence yang digunakan berdasarkan aspek-aspek yang dikemukakan oleh Lauster (1978) yaitu: (1) rasa aman, (2) ambisi normal, (3) keyakinan pada kemampuan diri, (4) mandiri, (5) toleran, (6) optimis, (7) bertanggung jawab, (8) mudah menyesuaikan diri.

\section{Teknik Analisis Data}

Pada tahap ini peneliti melaksanakan analisis terhadap seperangkat data yang telah diperoleh dari nilai KAM, kemampuan representasi matematis (pretes dan postes) dan skala self confidence (pretes dan postes) untuk di analisis secara kuantitatif. Pengolahan skor pretest dan postest untuk menentukan gain ternormalisasi (normalized gain).Untuk menghitung gain ternormalisasi digunakan rumus (Hake, R: 2007)

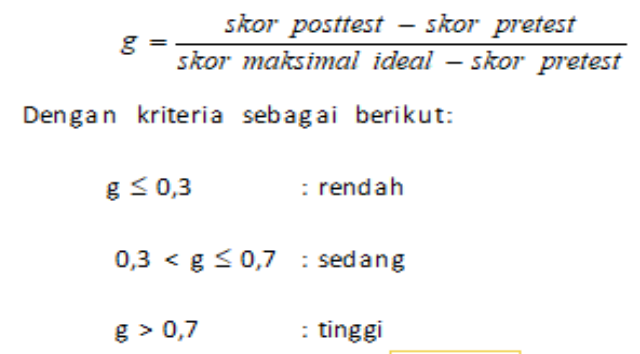

Setelah diperoleh nilai gain ternormalisasi, maka perlu dilakukan uji normalitas dan uji homogenitas. 


\section{HASIL}

Tujuan dari penelitian ini adalah untuk menelaah peningkatan representasi matematis dan self confidence siswa Sekolah Menengah Atas melalui pembelajaran humanistik berbasis PMR dengan siswa pembelajaran konvensional. Selain itu untuk mengetahui interaksi antara strategi pembelajaran dan peringkat siswa (tinggi, sedang dan rendah) terhadap representasi matematis siswa. Data yang diperoleh dan dianalisis dalam penelitian ini berupa nilai hasil pretes, postes dan n-gain pada representasi matematis dan self confidence siswa kelas eksperimen dan kelas kontrol. Pengolahan data dilakukan dengan menggunakan Microsoft Office Excel 2007, SPSS 20. berikut uraian data hasil penelitian dan pembahasannya.

\section{Analisis Data Hasil Penelitian Representasi Matematis}

Data hasil tes kemampuan representasi matematis siswa terdiri dari pretes dan postes yang berbentuk uraian dengan skor maksimum setiap butir adalah 12. Gain ternormalisasi kemampuan representasi matematis siswa diperoleh dari selisih skor postes dengan pretes dibagi selisih skor maksimum (ideal) dengan skor pretes. Nilai rata-rata n-gain merupakan gambaran peningkatan kemampuan representasi matematis siswa berdasarkan kemampuan awal matematika (tinggi, sedang, rendah) pada pembelajaran Humnistik berbasis PMR dan pembelajaran biasa.. Hasil rangkuman disajikan pada tabel berikut ini.

Tabel 1.

Rata-rata Data Indeks N-Gain Kemampuan Representasi Matematis Siswa Setiap Indikator

\begin{tabular}{|l|c|c|}
\hline \multicolumn{1}{|c|}{ Indikator } & Kelas Eksperimen & Kelas Kontrol \\
\hline Indikator 1 & 0,834 & 0,698 \\
\hline Indikator 2 & 0,743 & 0,560 \\
\hline Indikator 3 & 0,583 & 0,531 \\
\hline
\end{tabular}

Data pada tabel 1. di atas menunjukkan bahwa peningkatan masing-masing indikator ditinjau dari keseluruhan siswa lebih tinggi pada kelas yang diajar dengan model pembelajaran Humnistik berbasis PMR dibandingkan dengan kelas yang diajar dengan pembelajaran biasa. Kemampuan representasi matematis pada indikator ke-1 di kedua kelas (eksperimen dan kontrol) jauh lebih tinggi dibandingkan pada indikator ke-2 ataupun indikator ke-3 hal ini disebabkan pada indikator 1 yaitu kemampuan representasi siswa dalam membuat kata-kata atau teks tertulis merupakan kemampuan yang mudah dilakukan siswa. Disisi lain peningkatan kemampuan representasi matematis siswa lebih mudah ditingkatkan karena merupakan aspek kognitif yang mencakup kemampuan intelektual. Hal ini sesuai dengan teori belajar vigotsky dimana kemajuan perkembangan kognitif anak diperoleh sebagai hasil interaksi sosial dengan orang lain. Rata-rata indeks Normalized Gain (N-Gain) kemampuan representasi matematis siswa berdasarkan KAM siswa. Hasil rangkuman disajikan pada Tabel berikut. 


\section{Tabel 2.}

Rata-rata N-Gain Kemampuan Representasi Matematis Kelas Eksperimen dan Kelas Kontrol Berdasarkan KAM Siswa

\begin{tabular}{|c|c|c|c|}
\hline \multirow{2}{*}{ Pembelajaran } & Kemampuan Awal & \multicolumn{2}{|c|}{ Kemampuan Representasi Matematis } \\
\cline { 2 - 4 } & Matematika & $\overline{\boldsymbol{X}}$ & Sd \\
\hline \multirow{3}{*}{ PBM } & Tinggi & 0,790 & 0,020 \\
\cline { 2 - 4 } & Sedang & 0,715 & 0,074 \\
\cline { 2 - 4 } & Rendah & 0,610 & 0,023 \\
\hline \multirow{3}{*}{ Biasa } & Tinggi & 0,710 & 0,020 \\
\cline { 2 - 4 } & Sedang & 0,610 & 0,023 \\
\cline { 2 - 4 } & Rendah & 0,560 & 0,021 \\
\hline
\end{tabular}

Berdasarkan gambar di atas rata-rata n-gain kelompok eksperimen lebih tinggi daripada kelompok kontrol. Signifikansi dari kesimpulan di atas dapat diketahui dengan melakukan pengujian statistik dengan ANAVA dua jalur. Uji statistik dengan ANAVA dua jalur ini digunakan untuk menguji perbedaan peningkatan kemampuan representasi matematis berdasarkan faktor pembelajaran (PBM dan pembelajaran biasa) dan faktor kemampuan awal matematika siswa terhadap peningkatan kemampuan representasi matematis siswa.

\section{Analisis Peningkatan Kemampuan Representasi Matematis Berdasarkan Faktor Pembelajaran}

Analisis peningkatan kemampuan representasi matematis berdasarkan faktor pembelajaran dan kemampuan awal diuraikan melalui langkah-langkah menghitung normalitas dan homogenitas $n$ gain kemampuan representasi matematis kelompok eksperimen dan kontrol.

\section{Uji Normalitas}

Uji normalitas data indeks $N$-Gain juga dilakukan dengan menggunakan uji Lilliefors. Berikut ini hipotesis untuk uji normalitas:

$\mathrm{H}_{0} \quad$ : Sampel berasal dari populasi yang berdistribusi normal

$\mathrm{H}_{\mathrm{a}}$ : Sampel berasal dari populasi yang tidak berdistribusi normal

Ringkasan hasilnya disajikan pada tabel berikut.

\section{Tabel 3.}

Hasil Uji Normalitas Data Indeks N-Gain Kemampuan Representasi Matematis Siswa

\begin{tabular}{|c|c|c|c|}
\hline Kelas & $\mathbf{N}$ & $\mathbf{L}_{\mathbf{0}}$ & $\mathbf{L}_{\text {tabel }}$ \\
\hline Eksperimen & 30 & 0,1150 & 0,146 \\
\hline Kontrol & 30 & 0,142 & 0,161 \\
\hline
\end{tabular}

Pada Tabel di atas ditunjukkan bahwa pada kelas eksperimen dan kelas kontrol, $\mathrm{L}_{0}<\mathrm{L}_{\text {tabel. }}$. Dengan demikian $\mathrm{H}_{0}$ diterima, sehingga dapat disimpulkan bahwa sampel berasal dari populasi yang berdistribusi normal. Hasil yang sama juga ditunjukkan oleh perhitungan uji normalitas yang menggunakan uji kolmogorov smirnov melalui SPSS 20.

\section{Uji Homogenitas}

Uji homogenitas adalah pengujian sama tidaknya variabel-variabel dua buah distribusi atau lebih. Pengujian homogenitas ini menggunakan uji varians dua buah peubah bebas. Uji homogenitas 
dilakukan dengan menggunakan uji $\mathrm{F}$ dengan taraf signifikansi $\alpha=0,05$. Adapun rumusan hipotesis statistik untuk menguji homogenitas varians kedua kelompok data adalah :

$\mathrm{H}_{0}: \sigma_{1}^{2}=\sigma_{2}^{2}$ : Kedua sampel berasal dari populasi yang memiliki varians yang homogeny

$\mathrm{H}_{\mathrm{a}}: \sigma_{1}{ }^{2} \neq \sigma_{2}{ }^{2}$ : Kedua sampel berasal dari populasi yang memiliki varians yang tidak homogen Kriteria pengujian yang digunakan adalah:

jika $F_{\text {hitung }} \leq \mathrm{F}_{\text {tabel }}$ maka varians kedua kelompok homogen.

\section{Tabel 4.}

Hasil Uji Homogenitas Varians N-Gain Kemampuan Representasi Matematis Siswa

\begin{tabular}{|c|c|c|c|c|}
\hline Kelompok & Varians $\left.\mathbf{( s}^{\mathbf{2}}\right)$ & $\mathbf{F}_{\text {hitung }}$ & $\mathbf{F}_{\text {tabel }}$ & Kesimpulan \\
\cline { 1 - 2 } Eksperimen & $7,88 \times 10^{-3}$ & \multirow{2}{*}{1,325} & 1.75 & Homogen \\
\hline Kontrol & $6,230 \times 10^{-3}$ & & & \\
\hline
\end{tabular}

Berdasarkan Tabel 4 tersebut diperoleh bahwa pada taraf signifikan sebesar 5\% atau $\propto=0,05$ dengan $\mathrm{df}_{\text {pembilang }}$ sebesar 29 dan $\mathrm{df}_{\text {penyebut }}$ sebesar 29 diperoleh $\mathrm{F}_{\text {hitung }}<\mathrm{F}_{\text {tabel, }}$ yaitu 1,325 $<1,75$. Sehingga $\mathrm{H}_{0}$ diterima dan $\mathrm{H}_{\mathrm{a}}$ ditolak. Dengan demikian varians $\mathrm{N}$-Gain kemampuan representasi matematis siswa pada kelas eksperimen dan kelas kontrol homogen. Hasil yang sama juga ditunjukkan oleh perhitungan homogenitas yang menggunakan uji Levene melalui SPSS 20

\section{Analisis Data Hasil Penelitian Self Confidence}

Data self confidence diperoleh dari hasil pengisian skala self confidence pada pertemuan pertama dan pertemuan terakhir. Data yang diperoleh berupa data ordinal sehingga sebelum diolah menggunakan uji statisitik, data tersebut harus terlebih dahulu di konversi menjadi data interval dengan menggunakan Method of "Successive Interval (MSI). Rata-rata skor self confidence pretes kelas eksperimen adalah 22,57 dengan skor maksimum 33 dan skor minimumnya 15. Sedangkan rata-rata self confidence skor pretes kelas kontrol adalah 20,45 dengan skor maksimum 30 dan skor minimumnya 12. Hasil tersebut menunjukkan bahwa rata-rata hasil skor self confidence siswa kelas eksperimen relatif lebih tinggi dengan rata-rata siswa kelas kontrol.

\section{Uji Normalitas Data Pretes Self Confidence}

Untuk menguji normalitas pada penelitian ini digunakan uji Kolmogorov-smirnov dengan perumusan hipotesis pengujian normalitas sebagai berikut: Dengan menggunakan taraf signifikasi $\alpha=$ 0,05 maka kriteria pengujiannya adalah sebagai berikut:

1. Terima $\mathrm{H}_{0}$ jika nilai sig. $\geq \alpha$

2. Tolak $\mathrm{H}_{0}$ jika nilai sig. $<\alpha$

Hasil dari analisis normalitas uji kolmogorov-smirnov untuk data self confidence siswa kelas eksperimen dan kelas control terlihat bahwa skor awal self confidence siswa kelas eksperimen memiliki nilai signifikansi yang lebih besar dari $\alpha=0,05$ yaitu 0,087 untuk kelas eksperimen dimana $\mathrm{H}_{0}$ diterima atau dengan kata lain data self confidence awal berasal dari populasi yang berdistribusi normal dan pada kelas kontrol memiliki nilai signifikansi yang lebih besar dari $\alpha=0,05$ yaitu 0,070 
dimana berasal dari populasi yang berdistribusi normal. Karena kedua kelas berdistribusi normal, maka selanjutnya dilakukan uji homogenitas varians.

\section{Uji Homogenitas Data Pretes Self Confidence}

Uji homogenitas varians populasi data self confidence kelas eksperimen dan kelas kontrol dilakukan dengan Uji Levene statistik menggunakan SPSS 16.0 pada taraf signifikansi $\alpha=0,05$. Hipotesis statistik yang akan diuji adalah:

$$
\begin{aligned}
& H_{o}: \sigma_{1}^{2}=\sigma_{2}^{2} \\
& H_{1}: \sigma_{1}^{2} \neq \sigma_{2}^{2}
\end{aligned}
$$

Keterangan, $\quad \sigma_{1}^{2}=$ Varians populasi kelas eksperimen

$$
\sigma_{2}^{2}=\text { Varians populasi kelas kontrol }
$$

Diperoleh bahwa pada aspek representasi matematis dengan nilai $F=1.706$ dan $\operatorname{Sig}(0,06)<0,05$ maka $H_{o}$ diterima artinya varians skor pretes self confidence kedua kelas homogen. Setelah diketahui bahwa data kedua kelas memiliki varians yang homogen, maka langkah selanjutnya adalah menguji perbedaan peningkatan self confidence dengan menggunakan Uji -t.

\section{Uji Perbedaan Rata-rata Pretest Self confidence Siswa}

Uji perbedaan rata-rata pretes self confidence dilakukan untuk mengetahui bahwa tidak adanya perbedaan yang signifikan pada kemampuan awal siswa kelas eksperimen dan kelas kontrol. Self confidence menunjukkan bahwa nilai sig.(2-tailed) skor pretest adalah 0,000 yang berarti kurang dari $\alpha=0,05$ sehingga $\mathrm{H}_{0}$ ditolak. Hal ini berarti bahwa terdapat perbedaan yang signifikan antara skor pretest kelas eksperimen dengan skor pretest kelas kontrol. Jadi, dapat disimpulkan bahwa kedua kelas ini memiliki kemampuan awal yang tidak terlalu berbeda secara signifikan.

\section{Analisis Peningkatan Self confidence}

Analisis peningkatan self confidence pada kedua kelas yaitu kelas eksperimen dan kelas kontrol. Pengujian terhadap peningkatan self confidence siswa pada kelas eksperimen dan kelas kontrol dilakukan dengan menganalisis data gain ternormalisasi (N-gain). Rataan gain ternormalisasi merupakan gambaran peningkatan self confidence setelah mengikuti pembelajaran, baik yang mengikuti pembelajaran dengan humanistik berbasis PMR (kelas eksperimen) maupun yang mengikuti pembelajaran dengan pendekatan konvensional (kelas kontrol).

Perhitungan menggunakan SPSS 16.0 pada taraf signifikansi $\alpha=0,05$. Kriteria pengujian adalah tolak $H_{o}$ apabila Sig.(1-tailed) < taraf signifikansi (Uyanto, 2009:145). Perhitungan selengkapnya dapat dilihat pada lampiran, rangkuman hasil perhitungan dari SPSS dapat dilihat pada tabel berikut.

\section{Tabel 5.}

Uji Perbedaan Rata-rata N-Gain Self confidence Siswa

\begin{tabular}{cccc}
\hline Kelas & $\mathbf{t}$ & Sig. (2-tailed) & Sig. (1-tailed) \\
\hline $\mathrm{N}$-gain & 3.159 & .045 & .022 \\
\hline
\end{tabular}


Dari tabel 5 dapat dilihat bahwa pada gain self confidence siswa dengan nilai $t=3,159$ dan Sig. (2-tailed) = 0,045. Karena menurut Uyanto (2009:145) melakukan uji hipotesis satu sisi (1-tailed) maka nilai Sig. (2-tailed) harus dibagi dua menjadi nilai Sig. (1-tailed) =0,022. Karena nilai Sig. (1tailed $)<$ taraf Signifikansi $(\alpha=0,05)$, maka $H_{o}$ ditolak. Sehingga dapat disimpulkan bahwa rata-rata gain ternormalisasi self confidence siswa kelas eksperimen lebih baik dari rata-rata N-Gain kelas kontrol.

Hipotesis di atas dapat disimpulkan bahwa peningkatan self confidence siswa yang memperoleh pembelajaran humanistik berbasis PMR lebih baik daripada siswa yang memperoleh pembelajaran konvensional

\section{Uji Anava Data N-Gain Self confidence}

Berdasarkan hasil pengujian sebelumnya, diketahui bahwa data N-gain self confidence kedua kelas berdistribusi normal dan variansinya juga homogen sehingga statistik yang digunakan untuk menguji hipotesis penelitian adalah uji parametrik yaitu uji anava dua jalur. Analisis ini dilakukan untuk mengetahui pengaruh dari pemberian dua perlakuan yang berbeda pada kedua kelas yang menjadi sampel penelitian terhadap peningkatan self confidence siswa berdasarkan subkelompok siswa. Hasil perhitungan uji anava dua jalur dilakukan dengan bantuan SPSS versi 16 pada taraf signifikansi $\alpha=$ 0,05 dan kriteria pengujian adalah sebagai berikut:

Terima $\mathrm{H}_{0}$ jika nilai sig. $\geq \alpha$ dan Tolak $\mathrm{H}_{0}$ jika nilai sig. $<\alpha$

Berdasarkan hasil perhitungan anava dua jalur dapat disimpulkan bahwa subkelompok siswa memberikan pengaruh yang signfikan terhadap peningkatan self confidence siswa. Hal ini terlihat dari nilai sig. yang diperoleh untuk pembelajaran yaitu 0,027 dan nilai ini lebih kecil dari taraf signifikansi yang telah ditetapkan yaitu 0,05 sehingga berdasarkan kriteria pengujian maka $\mathrm{H}_{0}$ ditolak atau dengan kata lain $\mathrm{H}_{\mathrm{a}}$ diterima.

\section{Interaksi antara Model Pembelajaran dengan Peringkat Siswa terhadap representasi matematis}

Hipotesis yang diajukan:

$\mathrm{H}_{0}$ : Tidak terdapat interaksi antara strategi pembelajaran dengan peringkat siswa terhadap representasi matematis

$\mathrm{H}_{1}$ : Terdapat interaksi antara strategi pembelajaran dengan peringkat siswa terhadap representasi matematis

Perhitungan menggunakan SPSS 16.0 dengan menggunakan Uji Anova Two- Way pada taraf signifikansi $\alpha=0,05$. Kriteria pengujian adalah tolak $H_{o}$ apabila Sig. $<$ taraf signifikansi $\alpha=0,05$ berikut rangkuman pada tabel.

Tabel 6.

Interaksi antara Model Pembelajaran dengan Peringkat Siswa terhadap Representasi matematis

\begin{tabular}{|l|c|c|c|}
\hline Pembelajaran & Sig. & Kesimpulan & Ket \\
\hline $\begin{array}{l}\text { Pembelajaran humanistik } \\
\text { berbasis PMR }\end{array}$ & 0.000 & Tolak $\mathrm{H}_{0}$ & $\begin{array}{l}\text { Terdapat } \\
\text { interaksi }\end{array}$ \\
\cline { 1 - 2 } Pembelajaran konvensional & & &
\end{tabular}


Pada tabel diatas jelas bahwa Sig. $0.000<$ taraf signifikansi $\alpha=0,05$, maka Ho ditolak. Hal ini menunjukkan bahwa terdapat interaksi antara model pembelajaran (humanistik berbasis PMR dan pembelajaran konvensional) dan peringkat siswa (tinggi, sedang dan rendah) terhadap representasi matematis siswa.

\section{Interaksi antara Model Pembelajaran dengan Peringkat Siswa terhadap self confidence}

Peningkatan self confidence siswa pada kelas eksperimen lebih tinggi daripada kelas kontrol. Sedangkan hipotesis statistik untuk melihat interaksi antara faktor pembelajaran dan KAM terhadap self confidence siswa. Pengujian dilakukan dengan ANAVA dua jalur. Hasil pengujian menunjukkan bahwa kelompok data $n$-gain self confidence beasal dari populasi yang berdistribusi normal dengan varians masing-masing pasangan kelompok data homogen, maka selanjutnya dilakukan analisis statistik ANAVA dua jalur menggunakan SPSS 20.

Berdasarkan perhitungan uji ANAVA dua jalur gain ternormalisasi self confidence diketahui bahwa nilai $F$ pada faktor pembelajaran sebesar 33,835 dengan nilai signifikansi 0,00 lebih kecil dari taraf signifikansi 0,05. Sedangkan nilai F berdasarkan KAM 104,25 dengan taraf signifikansi 0,00, sehingga $\mathrm{H}_{0}$ ditolak. Dengan kata lain, terlihat bahwa untuk faktor pembelajaran yang berhubungan dengan kemampuan matematika siswa diperoleh nilai F sebesar 2,125 dengan nilai signifikansi sebesar 0,120 lebih besar dari taraf signifikansi yaitu 0,05 , sehingga $\mathrm{H}_{0}$ diterima. Maka dapat disimpulkan bahwa tidak terdapat interaksi antara pembelajaran dan kemampuan awal siswa (tinggi, sedang dan rendah) terhadap peningkatan self confidence siswa.

Pnelitian ini meneliti tentang peningkatan kemamuan representasi mateatis dan self confidence siswa. Kemampuan representasi matematis sangat dibutukan dalam setiap pembelajaran khususnya matematika, dimana siswa dituntut untuk berpikir secara aktif dan mandiri. Hal tersebut sejalan juga terhadap peningkatan self confidence siswa dalam menunjang proses berpikir siswa.

Berdasarkan hasil pretes dan pos test untuk representasi matematis dan self confidence siswa terbukti secara signifikan bahwa pembelajaran humanistik berbasis PMR sangat membantu dan mampu mengembangkan pola pikir siswa secara aktif. Pembelajaran humanistik berbasis PMR ini mampu menekankan keaktifan siswa dalam mempresentasikan dan mengkronstruksi pengetahuannya sendiri dan mampu merancang model-model yang sesuai dengan permasalahan matematika dalam kehidupan sehari-hari.

Peningkatan self confidence siswa berdasarkan hasil pretes dan postes yang diberikan pembelajara humanistik berbasis PMR lebih baik dari pada pembelajaran yang sering digunakan di sekolah tersebut. Hal tersebut terlihat dari data yang telah diperoleh di atas. Peningkatan self confidence siswa dikarenakan oleh aktifitas siswa selama diskusi di kelas yang mampu mempengaruhi perkembangan psikologis siswa dalam berpendapat sesama temannya. Dimulai dari penemuan penyelesaian masalah matematika, berinteraksi sesama teman atau berkelompok. Secara tak langsung pembelajran humanistik berbasis PMR memiliki dampak positif terhadap peningkatan representasi 
Peningkatan Kemampuan Representasi Matematis dan Self Confidence Siswa Melalui Pembelajaran Humanistik Berbasis Pendidikan Matematika Realistik, Lia Rista, Cut Yuniza Eviyanti, Siti Hadijah

matematis dan self confidence siswa. Hal tersebut terliht dari selama prose belajar mengajar berlangsung di kelas.

\section{KESIMPULAN}

Berdasarkan hasil analisis data penelitian tentang kemampuan representasi matematis dan selfconfidence siswa yang diajar melalui pembelajaran humanistik berbasis PMR dan pembelajaran biasa, maka diperoleh beberapa kesimpulan 1) Peningkatan kemampuan representasi matematis siswa yang memperoleh pembelajaran humanistik berbasis PMR (kelompok eksperimen) lebih tinggi daripada siswa yang memperoleh pembelajaran biasa (kelompok kontrol). 2) Peningkatan self confidence siswa yang memperoleh pembelajaran humanistik berbasis PMR (kelompok eksperimen) lebih tinggi daripada siswa yang memperoleh pembelajaran biasa (kelompok kontrol). 3) Terdapat interaksi antara model pembelajaran dan kemampuan awal terhadap peningkatan kemampuan representasi matematika siswa. 4) Terdapat interaksi antara model pembelajaran dan kemampuan awal terhadap peningkatan self confidence siswa.

\section{DAFTAR PUSTAKA}

Amalia, dkk. 2015. Penerapan Model Elicting Activities untuk Meningkatkan Kemampuan Berpikir Kreatif Matematis dan Self Confidence Siswa SMA.. Vol. 2, No. 2. Jurnal Didaktik Matematika

Hake, R. 2007. Design-Based Research In Physics Education: A Review in A.E. Kelly, R.A. Lesh, \& J.Y. Baek, eds. (in press), Handbook of Design Research Methods in Mathematics, Science, and Technology Education. Erlbaum

Mruk, CJ. (2006)., self esteem reserch, theory and practice: to ward a positive psychology of self esteem, 3rd Ed. New York: Springer Publishing co

Sj, Susilo. (2008). Matematika Perlu Disajikan Secara Humanis. Yogyakarta: Guru Besar Bidang Matematika Fakultas Sains dan Teknologi Dharma (USD)

Siswono. (2007). Pembelajaran Matematika Humanistik yang Mengembangkan Kreativitas Siswa.

Seminar nasional pendidikan Matematika yang Memanusiakan Manusia

Syahputra, E. 2016. Statistika Terapan. Medan: UNIMED PRESS

Uyanto. (2009). Pedoman Analisis Data dengan SPSS. Jakarta: Graha Ilmu. 